\title{
Proceeding
}

Supplementary Issue: Spring Conferences of Sports Science. Costa Blanca Sports Science Events, 19-20 June 2020. Alicante, Spain.

\section{Oblique didactics: Innovating the ludic experience in kindergarten to promote pedagogical training}

DAVIDE DI PALMA $\triangle$, PATRIZIA BELFIORE

Parthenope University, Naples, Italy

\begin{abstract}
The ludic experience through the discovery of body and movement in kindergarten is represented by an experience of fundamental importance for the pedagogical development of children. Also, in this case, it is necessary to research for innovative didactic proposals that motivate the children and lay the foundations for an effective training course. The purpose of this paper is to analyse, with a sample of children aged between 4 and 6 years, oblique-type didactics that can be used to evaluate the training progress obtainable through this innovative approach, and to hypothesize its use in kindergarten.

Keywords: Oblique didactics; Didactic innovation; Kindergarten; Experimental pedagogy; Playful-Motor; Pedagogical development.

\section{Cite this article as:}

Di Palma, D. \& Belfiore, P. (2020). Oblique didactics: Innovating the ludic experience in kindergarten to promote pedagogical training. Journal of Human Sport and Exercise, 15(3proc), S531-S538. doi:https://doi.org/10.14198//hse.2020.15.Proc3.06
\end{abstract}

Corresponding author. Parthenope University, Naples, Italy.

E-mail: davide.dipalma@uniparthenope.it

Supplementary Issue: Spring Conferences of Sports Science. Costa Blanca Sports Science Events, $19-20$ June 2020. Alicante, Spain.

JOURNAL OF HUMAN SPORT \& EXERCISE ISSN 1988-5202

(c) Faculty of Education. University of Alicante

doi:10.14198/jhse.2020.15.Proc3.06 


\section{INTRODUCTION}

Children play with their body and learn new things by means of it. The activities that focus on corporeity and movement are manifold, and almost all of them are related to the concepts of motor skills, motor education, pedagogy and didactics of movement and psychomotricity.

Motor skills refer to the set of functioning mechanisms of the central and peripheral apparatus and structures of the human organism; they play a fundamental role in the early stages of the child's development, since they represent the way in which the child learns about both the surrounding environment and his or her possibilities of action (Bertagna, 2004; Boyce, Coker \& Bunker, 2006; Coco, 2014; Quennerstedt, Öhman \& Armour, 2014).

On the other hand, we could say that motor education has a double meaning: the first refers to the contribution made by the movement experiences to the comprehensive pedagogical shaping of the individual's personality, while the second refers strictly to the school subject, which is still erroneously referred to as "physical education". In this second definition, two macro-directions of the didactic-educational process could be identified (Ascione, Di Palma, Rosa, 2019; Di Palma \& Ascione, 2020; Di Palma, Maulini, Ascione, 2020):

1. Learning to move - which includes, for example, learning motor and mimic-gestural skills, increasing knowledge about the activities carried out and developing perceptive, coordination and conditional skills;

2. Moving to learn- which is promoted not only through the identification of specific objectives in the motor field, but also by means of educational values.

Psychomotricity can be understood as a specific activity, but also as a cross-sectoral approach that emphasizes and enhances the synergy between movement and mental image, action and inner world, action and intentionality, all considered in a perspective of personal and social integration of the individual. Over time, the term has undergone a significant transformation, until reaching the current educational meaning it is attached today (Dumitru, 2018; Formenti, 2006; Mas \& Castellà, 2016; Vayer, 1992). Psychomotricity deals with certain educational and pedagogical aspects within the child, such as:

- The perception and structuring of space and time as fundamental elements in perceiving the dimension of reality;

- The pro-verbal game and the motor sense in the discovery of reality and in self-expression;

- The development of the symbolic game in the shaping of thoughts and identity;

- The development of socialization in the different stages of growth.

When the adult decides to propose psychomotor experiences, he or she defines situations that favour the integration of several components such as that operational, emotional, motor and cognitive. All psychomotor proposals consider the dimensions through which the individual expresses himself/herself to be closely interconnected:

- Physical-functional dimension, which refers to corporeity in the strict sense;

- Cognitive dimension, which is not linked to the simple given movement;

- Affective-relational dimension, promoted by movement, which can also convey other meanings;

Obviously, depending on the objectives and goals to be achieved, a specific psychomotor model is chosen based on one or more of the above-mentioned dimensions. An interesting model that particularly attracted our attention, and on which we based our project, is that worked out by Bernard Aucouturier (Aucouturier, 
2005), which takes into account the connection between the physical-functional and the affective-relational dimensions. The author mainly intends to pursue these objectives:

- Encouraging people to express their inner world;

- Fostering the development of the symbolic function through the pleasure of action and game;

- Supporting the development of reassurance processes through the adult's empathy and the game.

The aspect that most impressed us about the author is that, although focusing on two of the three dimensions of the individual, he also took into account the cognitive sphere, with the further objective of encouraging the development of the distancing processes in children which lead them to operational thinking. In this way, this theoretical approach turns into a potential didactic and formative model to be adopted in practice, in order to foster children's growth. This model is based on the concept of obliquity, or rather on oblique didactics. Obliquity is defined as a context of action in which all the subjects can work according to "their own level", i.e. according to their own characteristics, and can enjoy their own self-value. A situation is considered oblique when all the members of a group, while doing different things, feel that they are engaged in the same activity simultaneously and that they respond adequately to the adult's requests, which would not happen if the adult let the subjects do different activities. In this regard, an experimental didactic and pedagogical project is proposed in order to evaluate the educational effectiveness of an oblique didactic proposal in kindergarten, oriented to recreational-motor activities.

\section{EXPERIMENTAL DIDACTIC-PEDAGOGICAL PROJECT IN KINDERGARTEN}

After this short theoretical introduction, in which the concepts of motor skills, motor education, psychomotricity and oblique approach have been expressed, we will now move on to presenting our project.

It all started by observing a group of children who were little stimulated and interested in playing traditional games, which included pre-set unidirectional paths. Based on what we observed, we opted for a new didactic proposal based on the concept of obliquity. It is necessary to underline the innovative nature of this choice, given that there are very few references in the literature related to oblique psychomotor activity; nevertheless, it seemed appropriate to focus attention on a new approach that would differ from all those we already knew, thanks to its ability to connect the experience of the movement to the positive idea of the self, coinciding with self-efficacy.

Thanks to a cultural sports association operating in kindergartens, which employed psychomotor activities among the various courses, we managed to involve a group of 10 children of both sexes aged between 4 and 6 years, meeting them twice a week for a month, for a total of 8 meetings.

We proposed them 3 types of activities that would improve their basic motor patterns (including jumping) and involve them fully in the construction phase of the activity, through the use of poor materials to be reinvented. These "poor" materials, in technical terms, are defined as unstructured materials that do not have a specific functionality in relation to motor and psychomotor activity; however, they are somehow "borrowed" from other areas to stimulate divergent body-motor experiences.

It is important to point out that the order in which the proposed activities are described is not random: in terms of difficulty, they were carried out from the easiest to the most difficult in order to monitor and evaluate, in the best way possible, the children's motor evolution promoted by the innovative oblique psychomotor educational approach. 
Table 1. The didactic activities of the experimental proposal.

\begin{tabular}{|l|l|}
\hline 1st PROPOSED ACTIVITY: "Jump bravely!" & $\begin{array}{l}\text { The activity involved arranging a rope, which was } \\
\text { attached onto a low support on one side, whilst the } \\
\text { other side was attached to a slightly higher support, } \\
\text { so that an oblique line was created. The children } \\
\text { were asked to place themselves at any point on the } \\
\text { rope and to jump with both feet to reach the } \\
\text { opposite side. During the game, the educator let the } \\
\text { children freely choose the position to jump on, } \\
\text { encouraged the less reckless ones to jump little by } \\
\text { little to the highest points of the rope, and always } \\
\text { tried to give new stimuli to those who already } \\
\text { possessed better motor skills. }\end{array}$ \\
\hline METHODOLOGICAL-DIDACTIC NOTES & $\begin{array}{l}\text { During this activity, children were stimulated } \\
\text { through vocal inputs to experiment with and explore } \\
\text { the motor scheme of jumping, and to acquire } \\
\text { greater awareness of their own capabilities by } \\
\text { challenging their own limits. }\end{array}$ \\
\hline MATERIALS USED & \begin{tabular}{l} 
Recycled rope \\
\hline
\end{tabular} \\
\hline
\end{tabular}

\begin{tabular}{|l}
\hline 2nd PROPOSED ACTIVITY: "Moosgummi islets" \\
\hline DESCRIPTION OF THE ACTIVITY
\end{tabular}

METHODOLOGICAL-DIDACTIC NOTES

The activity required the educator to set up several moosgummi stations in the game area, and a big paperboard representing the point of arrival. The children were asked to jump autonomously onto the different moosgummies stations, which were amusingly called islets, in order to reach the finish line in the fastest way. During the game the educator encouraged the children to choose the best path to take.

During this activity, the children were stimulated to experiment with and explore space, improve the motor scheme of jumping and learn the concept of time, by encouraging them to jump onto as few islands as possible.

MATERIALS USED Moosgummi (craft foam), paperboard.

\section{3rd PROPOSED ACTIVITY: "The little paper clouds"} DESCRIPTION OF THE ACTIVITY

The activity required children to be provided with two sheets of newspaper: one was used for the starting point and the other was placed at the most suitable distance for the child so that they could move forward and recover the starting point, in order to reuse it in the next step. It was required to use the two sheets as if they were clouds, so as to 


\begin{tabular}{|l|l|}
\hline & $\begin{array}{l}\text { create a path to jump onto and get to the other side } \\
\text { of the game area as quickly as possible. The } \\
\text { educator could first show the children how to create } \\
\text { the path, due to the difficulty of the activity, and then } \\
\text { encourage them to do it on their own. }\end{array}$ \\
\hline METHODOLOGICAL-DIDACTIC NOTES & $\begin{array}{l}\text { During this activity the children were stimulated to } \\
\text { experiment with and explore the motor pattern of } \\
\text { jumping, acquire self-perception in space and } \\
\text { manage distances. }\end{array}$ \\
\hline MATERIALS USED & Sheet of newspaper. \\
\hline
\end{tabular}

\section{STRUCTURE OF THE EVALUATION PROCESS}

Our research work, just as it should be, is closely related to a structured evaluation process aimed at identifying the training evolution, and therefore the effectiveness, of the innovative proposal. By definition, evaluation is understood as the acquisition of elements allowing to verify the effectiveness of an educationalmotor intervention. For this project, we proposed two types of activities to children: one based on traditional exercises and the other based on motor games linked to the concept of obliquity. The first typology was carried out in the initial phase of the project, with subsequent evaluation to verify which were their starting skills; the second typology was implemented immediately after the first one, and remained unchanged until the end of the project; it ended with an evaluation phase to verify any improvements attained by the children thanks to this new approach. To do this, we made use not only of direct observation, but also of new technologies such as tablets and smartphones. All this in order to be able to record our meetings and review them afterwards, so that we could carefully analyse everything that could be of interest to us. Technically, to describe and analyse the level of each subject, we used an evaluation grid based on four key themes: knowledge, skills, abilities and interest (each one closely related to the didactic and pedagogical meaning of motor and sports sciences), consistent with the set objectives. Each theme was assigned a score from 1 to 6 , and each corresponded to the established requirements. Table 2 shows the above.

Table 2. Evaluation scheme for assigning a score.

\begin{tabular}{|c|l|l|l|l|}
\hline SCORE & \multicolumn{1}{|c|}{ KNOWLEDGE } & \multicolumn{1}{|c|}{ SKILLS } & ABILITIES & \multicolumn{1}{c|}{ INTEREST } \\
\hline 1 & $\begin{array}{l}\text { Shows no basic } \\
\text { motor schemes }\end{array}$ & $\begin{array}{l}\text { Cannot evaluate and } \\
\text { put into practice even } \\
\text { the simplest motor } \\
\text { actions }\end{array}$ & $\begin{array}{l}\text { Not gifted with } \\
\text { motor skills }\end{array}$ & $\begin{array}{l}\text { Shows rejection of } \\
\text { the subject }\end{array}$ \\
\hline 2 & $\begin{array}{l}\text { Fragmentarily } \\
\text { reworks basic motor } \\
\text { schemes }\end{array}$ & $\begin{array}{l}\text { Cannot apply the motor } \\
\text { actions and carry out } \\
\text { group work }\end{array}$ & $\begin{array}{l}\text { Shows poor motor } \\
\text { skills and } \\
\text { insufficient } \\
\text { understanding of } \\
\text { the rules }\end{array}$ & $\begin{array}{l}\text { Shows completely } \\
\text { uninterested in the } \\
\text { subject }\end{array}$ \\
\hline
\end{tabular}




\begin{tabular}{|c|c|c|c|c|}
\hline 3 & $\begin{array}{l}\text { Shows incorrect } \\
\text { motor expression }\end{array}$ & $\begin{array}{l}\text { Cannot analyse and } \\
\text { evaluate the action } \\
\text { carried out and its } \\
\text { outcome. Makes } \\
\text { mistakes even when } \\
\text { supported }\end{array}$ & $\begin{array}{l}\text { Shows partial } \\
\text { and imprecise } \\
\text { design of the } \\
\text { motor } \\
\text { sequences. } \\
\text { Fragmentarily } \\
\text { understands } \\
\text { rules and } \\
\text { techniques }\end{array}$ & $\begin{array}{l}\text { Shows partial } \\
\text { interest }\end{array}$ \\
\hline 4 & $\begin{array}{l}\text { Stores, selects and } \\
\text { uses } \\
\text { implementation } \\
\text { modalities, even if } \\
\text { superficially. }\end{array}$ & $\begin{array}{l}\text { Can evaluate and } \\
\text { apply motor sequences } \\
\text { in a sufficient but not } \\
\text { autonomous way }\end{array}$ & $\begin{array}{l}\text { Grasps the } \\
\text { meaning of the } \\
\text { rules sufficiently } \\
\text { by relating to } \\
\text { space and time. }\end{array}$ & $\begin{array}{l}\text { Shows sufficient } \\
\text { interest }\end{array}$ \\
\hline 5 & $\begin{array}{l}\text { Shows good } \\
\text { adaptability to the } \\
\text { motor sequence }\end{array}$ & $\begin{array}{l}\text { Can adapt to changing } \\
\text { motor situations, and can } \\
\text { apply motor sequences } \\
\text { both sufficiently and } \\
\text { autonomously }\end{array}$ & $\begin{array}{l}\text { Can manage } \\
\text { situations } \\
\text { autonomously, } \\
\text { understands and } \\
\text { stores techniques } \\
\text { correctly }\end{array}$ & $\begin{array}{l}\text { Shows interest and } \\
\text { attentiveness }\end{array}$ \\
\hline 6 & $\begin{array}{l}\text { Shows autonomous } \\
\text { expression and } \\
\text { excellent adaptability } \\
\text { to the motor } \\
\text { sequence with very } \\
\text { good performance } \\
\text { skills }\end{array}$ & $\begin{array}{l}\text { Critically and confidently } \\
\text { deals with the rules and } \\
\text { problems, and creatively } \\
\text { searches for innovative } \\
\text { solutions }\end{array}$ & $\begin{array}{l}\text { Masters both } \\
\text { conceptual } \\
\text { elaboration and } \\
\text { motor } \\
\text { experience by } \\
\text { designing the } \\
\text { most suitable } \\
\text { technical- } \\
\text { tactical } \\
\text { solutions for the } \\
\text { situation } \\
\text { autonomously } \\
\text { and quickly }\end{array}$ & $\begin{array}{l}\text { Shows particular } \\
\text { interest and makes } \\
\text { personal } \\
\text { contributions to the } \\
\text { lesson }\end{array}$ \\
\hline
\end{tabular}

\section{OUTCOMES AND OBSERVATIONS}

\section{Ex-ante evaluation}

After getting to know the children during the first meeting, in the following one we gave start the project by evaluating the group, according to the first type of activity proposed (i.e. the one based on classic games and the traditional didactic approach). The outcomes obtained for each child are shown in Table 3.

As we can see, particularly relevant are the outcomes reached by subject no. 6 and subject no. 8; the former obtained a minimum score for 3 of the 4 themes analysed, while the latter, on the contrary, obtained a very high score for all 4 themes analysed. On the whole, the sample group analysed showed:

- A minimum level of knowledge.

- A poor level of skills.

- A skills level that varies between minimum and poor. 
- A satisfactory level of interest in only 4 of the 10 subjects examined.

Table 3. Ex-ante evaluation outcomes.

\begin{tabular}{|l|c|c|c|c|c|c|c|c|c|c|}
\hline & \multicolumn{10}{|c|}{ Subject } \\
\cline { 2 - 13 } & $\mathbf{1}$ & $\mathbf{2}$ & $\mathbf{3}$ & $\mathbf{4}$ & $\mathbf{5}$ & $\mathbf{6}$ & $\mathbf{7}$ & $\mathbf{8}$ & $\mathbf{9}$ & $\mathbf{1 0}$ \\
\hline Knowledge & 3 & 2 & 3 & 2 & 2 & 1 & 3 & 4 & 3 & 2 \\
\hline Skills & 3 & 4 & 3 & 3 & 4 & 2 & 3 & 4 & 4 & 3 \\
\hline Abilities & 3 & 2 & 3 & 3 & 3 & 1 & 3 & 4 & 4 & 2 \\
\hline Interest & 2 & 3 & 5 & 1 & 4 & 1 & 2 & 4 & 5 & 3 \\
\hline
\end{tabular}

\section{Ex-post evaluation}

In the eighth and last meeting the group was evaluated again after the experimental didactic proposal, based on games and motor activities linked to the innovative concept of obliquity. The outcomes reached by each child are shown in Table 4.

Table 4. Ex-post evaluation outcomes.

\begin{tabular}{|l|c|c|c|c|c|c|c|c|c|c|}
\hline & \multicolumn{10}{|c|}{ Subject } \\
\cline { 2 - 12 } & $\mathbf{1}$ & $\mathbf{2}$ & $\mathbf{3}$ & $\mathbf{4}$ & $\mathbf{5}$ & $\mathbf{6}$ & $\mathbf{7}$ & $\mathbf{8}$ & $\mathbf{9}$ & $\mathbf{1 0}$ \\
\hline Knowledge & 5 & 4 & 5 & 3 & 4 & 3 & 5 & 6 & 4 & 3 \\
\hline Skills & 5 & 5 & 5 & 3 & 4 & 3 & 3 & 5 & 5 & 4 \\
\hline Abilities & 4 & 4 & 5 & 3 & 4 & 2 & 4 & 6 & 4 & 3 \\
\hline Interest & 5 & 5 & 6 & 4 & 5 & 4 & 5 & 6 & 6 & 5 \\
\hline
\end{tabular}

As we can see, the level attained by each subject in the different themes analysed definitely increased compared to the initial phase of the project. As for the subjects that in the ex-ante evaluation had obtained extremely relevant and opposite results, we found out that subject n. 6 , i.e. the one that started from a minimum level, recorded a considerable growth especially as regards the interest in the proposed activity; subject n. 8, i.e. the one that started from a very high level compared to the average, reached the highest score in 3 themes out of 4 . The theme that gave us particular satisfaction at the evaluation level was the one concerning the interest; it could be said that, without this element, learning (and therefore the improvement of the different focuses) would be extremely difficult and slower. A comprehensive analysis of the class group showed a clear improvement in all the items analysed.

\section{CONCLUDING REMARKS}

As evidenced by the outcomes of the ex-post evaluation, the oblique didactic approach proved to be effective and of great impact in the motor, motivational, relational and experiential fields, leading the children to a formative and pedagogical growth by acquiring greater awareness of themselves, their skills and potentialities. In addition, a remarkable feedback was also received from the less daring children with respect to motor activity, since they acquired both greater confidence and desire to learn, showing a strong willingness to continue working with this methodology. Nowadays, we are in a world in continuous evolution from all points of view, making it necessary to update didactics so that the educational contexts have a futureoriented dynamism. For this reason, the research work carried out is part of that sphere of the experimental pedagogical sciences that investigates the most effective and appropriate educational proposals, especially for students attending kindergarten and primary school; it is in that period that the foundations for structuring one's own future personal identity are laid. The experimental work performed, being oriented to a new didactic 
proposal in the motor field, can be an excellent starting point for creating and implementing innovative didactic protocols to be put in place both in non-formal educational contexts, such as those of associative and recreational-motor nature, but above all in formal ones too, like that of scholastic nature.

\section{CONTRIBUTIONS}

The manuscript is the result of a collective work by the authors, the specific contribution of which is to be referred to as follows: The "Introduction" and "Concluding Remarks" are to be attributed to Patrizia Belfiore, "Experimental Didactic-Pedagogical Project in Kindergarten" - "Structure of the Evaluation Process" "Outcomes and Observations" to Davide Di Palma.

\section{REFERENCES}

Ascione, A., Di Palma, D., \& Rosa, R. (2019). Innovative educational methodologies and corporeity factor. Journal of Human Sport and Exercise, 14(2proc), S159-S168. https://doi.org/10.14198/ihse.2019.14.proc2.02

Aucouturier, B. (2005). La méthode Aucouturier: Fantasmes d'action \& pratique psychomotrice. De Boeck Supérieur.

Bertagna, G. (Ed.). (2004). Scuola in movimento: la pedagogia e la didattica delle scienze motorie e sportive tra riforma della scuola e dell'università (Vol. 25). FrancoAngeli.

Boyce, B. A., Coker, C. A., \& Bunker, L. K. (2006). Implications for variability of practice from pedagogy and motor learning perspectives: finding a common ground. Quest, 58(3), 330-343. https://doi.org/10.1080/00336297.2006.10491886

Coco, D. (2014). Pedagogia del corpo ludico-motorio e sviluppo morale (Vol. 2014, pp. 1-224). Anicia.

Di Palma D., Maulini C., Ascione A. (2020). Stimulate formation in primary schools through an experimental motor education proposal "for all". sport science, vol. 13.

Di Palma, D., \& Ascione, A. (2020). Experimenting with motor and sports sciences in primary school: Innovative proposals for didactics and evaluation systems. Journal of Human Sport and Exercise, 15(2proc), S162-S172. https://doi.org/10.14198/ihse.2020.15.proc2.06

Dumitru, A. (2018). The stimulation of child psychomotricity by play and movement. Euromentor JournalStudies about education, 9(04), 84-104.

Formenti, L. (Ed.). (2006). Psicomotricità. Educazione e prevenzione. La progettazione in ambito socioeducativo. Edizioni Erickson.

Mas, M. T., \& Castellà, J. (2016). Can Psychomotricity improve cognitive abilities in infants?. Aloma: revista de psicologia, ciències de l'educació i de l'esport Blanquerna, 34(1), 65-70.

Quennerstedt, M., Öhman, M., \& Armour, K. (2014). Sport and exercise pedagogy and questions about learning. Sport, Education and Society, 19(7), 885-898. https://doi.org/10.1080/13573322.2013.847824

Vayer, P. (1992). Educazione psicomotoria nell'età scolastica. Armando Editore.

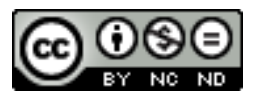

This work is licensed under a Attribution-NonCommercial-NoDerivatives 4.0 International (CC BY-NC-ND 4.0). 